University of Wollongong

Research Online

Faculty of Business - Papers (Archive)

Faculty of Business and Law

2012

The organizational virtuousness of strategic corporate social responsibility: a case study of the Sri Lankan family-owned enterprise MAS Holdings

Mario Fernando

University of Wollongong, mariof@uow.edu.au

Shamika Almeida

University of Wollongong, shamika@uow.edu.au

Follow this and additional works at: https://ro.uow.edu.au/buspapers

Part of the Business Commons

Research Online is the open access institutional repository for the University of Wollongong. For further information contact the UOW Library: research-pubs@uow.edu.au 


\title{
The organizational virtuousness of strategic corporate social responsibility: a case study of the Sri Lankan family-owned enterprise MAS Holdings
}

\begin{abstract}
Relatively little is known about strategic corporate social responsibility (CSR) in Asian companies. In the post-tsunami period, the authors interviewed 23 senior executives at ten prominent companies in Sri Lanka. Nine of the companies responded to the tsunami with philanthropy based CSR initiatives. Interviews with three senior executives at the family-owned enterprise MAS Holdings revealed an explicitly strategic CSR approach. MAS Holdings, an apparel manufacturer owned by three brothers, is Victoria Secret's lead strategic partner and an ethical buying source for other well-known apparel retailers. This paper examines the organizational virtuousness of MAS Holdings' strategic CSR initiatives. The analysis uses Bright et al.'s (2006) conceptualization of organizational virtuousness in terms of the three dimensions of human impact, moral goodness and unconditional societal betterment. The case study findings for MAS Holdings illustrate how strategic CSR initiatives could be virtuous due to positive contributions to the community in those dimensions despite generating profits, publicity and reputation advantageous to the firm. While the empirical findings are limited to one company in Sri Lanka in the posttsunami period, the paper discusses the broader implications of and directions for future research into the organizational virtuousness of strategic CSR.
\end{abstract}

\section{Keywords}

corporate social responsibility; strategic corporate social responsibility; organizational virtuousness; Asia; Sri Lanka

\section{Disciplines \\ Business}

\section{Publication Details}

Fernando, M. \& Almeida, S. (2012). The organizational virtuousness of strategic corporate social responsibility: a case study of the Sri Lankan family-owned enterprise MAS Holdings. European Management Journal, 30 (6), 564-576. 


\title{
The Organizational Virtuousness of Strategic Corporate Social Responsibility:
}

\section{A Case Study of the Sri Lankan Family-Owned Enterprise MAS Holdings}

\begin{abstract}
Relatively little is known about strategic corporate social responsibility (CSR) in Asian companies. In the post-tsunami period, 23 senior executives at ten prominent companies in Sri Lanka were interviewed. Nine of the companies responded to the tsunami with philanthropy based CSR initiatives. Interviews with three senior executives at the family-owned enterprise MAS Holdings revealed an explicitly strategic CSR approach. MAS Holdings, an apparel manufacturer owned by three brothers, is Victoria Secret's lead strategic partner and an ethical buying source for other wellknown apparel retailers. This paper examines the organizational virtuousness of MAS Holdings' strategic CSR initiatives. The analysis uses Bright, Cameron and Caza's (2006) conceptualization of organizational virtuousness in terms of the three dimensions of human impact, moral goodness and unconditional societal betterment. The case study findings for MAS Holdings illustrate how strategic CSR initiatives could be virtuous due to positive contributions to the community in those dimensions despite generating profits, publicity and reputation advantageous to the firm. While the empirical findings are limited to one company in Sri Lanka in the post-tsunami period, the paper discusses the broader implications of and directions for future research into the organizational virtuousness of strategic CSR.
\end{abstract}

Keywords: corporate social responsibility; strategic corporate social responsibility; organizational virtuousness; Asia; Sri Lanka 